\title{
Kinerja Ekspor Komoditas Primer terhadap Inflasi dan Nilai Tukar Pada Era Pandemi Di Indonesia : Pendekatan Prebisch Singer Hypothesis
}

\author{
Performance of Exports of Primary Commodities Towards Inflation and Exchange Rate In \\ The Pandemic Era In Indonesia: The Prebisch Singer Hypothesis Approach
}

\section{Shella Elly Sritrisniawati ${ }^{1}$, Evi Gravitiani ${ }^{2}$}

${ }^{1,2}$ Fakultas Ekonomi dan Bisnis, Universitas Sebelas Maret

Jl. Ir. Sutami No.36, Kentingan, Surakarta, Jawa Tengah 57126, Indonesia

${ }^{1}$ Korespondensi: shellasritrisniawati@gmail.com

[diterima: September 2021- revisi: November 2021-diterbitkan daring: Desember 2021]

\begin{abstract}
ABSTRAK
Perdagangan internasional berkontribusi penting dalam perkembangan ekonomi suatu negara. Salah satu pendekatan ekonomi yang fokus pada harga komoditas yaitu Raul Prebisch dan Hans Singer atau sering disebut Hipotesis Prebisch-Singer. Dengan adanya fenomena pandemi COVID-19 berdampak pada lemahnya ekonomi dunia. Tujuan penelitian untuk menganalisis hubungan jangka panjang dan kausalitas antara ekspor komoditas primer dalam penentuan harga serta untuk memaparkan kondisi pandemi sesuai dengan hipotesis tersebut. Penelitian ini menggunakan dua metode yaitu Cointegration dan Granger Causality. Variabel yang digunakan nilai volume ekspor dari beberapa komoditas primer terhadap inflasi dan nilai tukar. Pada periode bulanan dari tahun 2019-2021. Hasil estimasi menunjukkan hubungan searah antara nilai ekspor komoditas primer dengan inflasi dan juga pada nilai tukar. Hubungan jangka panjang tidak sesuai dengan Hipotesis Prebisch Singer. Pandemi COVID-19 mengakibatkan tingkat kinerja ekspor komoditas primer terganggu karena pembatasan kegiatan ekonomi (lockdown). Sehingga mengakibatkan tingkat harga komoditas primer mengalami penurunan sementara dan akan kembali stabil dimasa mendatang.
\end{abstract}

Kata Kunci : Prebisch Singer Hypotesis, Ekspor Komoditas Primer, Granger Causality, Cointegration

\begin{abstract}
International trade plays an important role in the economic development of a country. One economic approach that focuses on commodity prices is called Raul Prebisch and Hans Singer or often the PrebischSinger hypothesis. The COVID-19 pandemic has had an impact on the weakness of the world economy. The purpose of this study is to analyze the long-term and causality between exports of primary commodities in prices and to describe the pandemic conditions in accordance with this hypothesis. This study uses two methods, namely Cointegration and Granger Causality. The variables used are the value of the export volume of several primary commodities on inflation and exchange rates. In the monthly period from 2019-2021. The results show a unidirectional relationship between the value of primary commodity exports with inflation and also on the exchange rate. Long-term relationship is not in accordance with the Prebisch Singer Hypothesis. The COVID-19 pandemic has resulted in the disruption of the level of economic activity (lockdown). As a result, the primary price level has decreased and will return to stability in the future.
\end{abstract}

Keywords: Prebisch Singer Hypotesis, Export Primary Commodities, Granger Causality, Cointegration JEL classification: C01, C1, F11, F10, 


\section{PENDAHULUAN}

\section{Latar Belakang}

Perdagangan internasional dapat didefinisikan sebagai aktivitas ekonomi oleh dua negara atau lebih yang meliputi pertukaran barang dan jasa dengan tujuan untuk memenuhi kebutuhan suatu negara. Kegiatan tersebut dikenal dengan aktivitas ekspor maupun impor. Barang yang diperdagangkan berupa barang konsumsi (komoditas) maupun barang modal/manufaktur (Nurjaka dan Oman, 2003). Menurut Al-Yousif (2006) menjelaskan perdagangan dapat memiliki tujuan yang berbeda yaitu untuk memperoleh suatu keuntungan. Dalam tujuan mendapatkan keuntungan, suatu negara harus memiliki keunggulan komparatif atau memiliki spesialisasi atas produk tertentu. Sehingga negara tersebut akan mampu bersaing dengan negara lainnya. Kegiatan yang dilakukan oleh suatu negara untuk meningkatkan devisa salah satunya dengan ekspor. Deliarnov (2012) memaparkan bahwa dalam memperoleh keuntungan maksimal negara harus meningkatkan ekspor dan membatasi impor. Perdagangan internasional sebagai elemen ekonomi memberikan kontribusi yang penting dalam perkembangan perekonomian negara. Berkaitan dengan hal tersebut perlu upaya percepatan penyaluran komoditas dari suatu negara. Dengan demikian mampu memperluas pangsa pasar dan meningkatkan skala ekonomi. Semakin tinggi tingkat ekspor suatu komoditas maka negara tersebut akan mendapatkan keunggulan komparatif dan dapat melakukan spesialisasi produk/barang.

Salah satu pendekatan perdagangan internasional yaitu model Raul Prebisch dan Hans Singer atau terkenal dengan Prebisch dan Singer (1950) berpendapat bahwa terdapat penurunan dalam perdagangan di negara berkembang yang berkaitan dengan adanya industrialisasi. Selain itu juga menganalisis bahwa ekspor dari negara berkembang didominasi oleh barang primer atau komoditas primer. Analisis pergerakan harga barang primer di perdagangan dengan tren menurun (Bloch and Sapsford, 1997). Dalam hal ini terjadi efek negatif yang timbul antara harga barang primer dan frekuensi perdagangan. Hipotesis PrebischSinger menjelaskan keterkaitan barang primer yang menunjukkan tren menurun, sedangkan barang manufaktur mengalami peningkatan dalam jangka panjang. Penelitian juga dilakukan oleh Harvey, et al. (2010) yang menganalisis tentang hipotesis Prebisch-Singer di mana harga menunjukkan tren yang menurun disebabkan negara berkembang mengandalkan pendapatan ekspor dari komoditas primer. Tingkat ketergantungan pada komoditas primer mengimplikasikan kebijakan pada perilaku harga. Pada saat terjadinya Perang Dunia II pada sekitar tahun 1980-an di mana mendukung hipotesis ini dengan menemukan bahwa juga terjadi tren yang memburuk (Sapsford, 1985). Penelitian meneliti tentang pergerakan harga komoditas primer dalam jangka panjang. Terdapat bahwa masalah ketidakstabilan struktural yang berkontribusi pada tren yang memburuk yang mendukung hipotesis Prebisch Singer. Kim, et al. (2003) memaparkan harga pada tren nol, akan dapat kembali naik dalam jangka pendek. Pada teori perdagangan modern Hecksher-Ohlin/H-O menurut Salvatore (2013:129) memaparkan bahwa negara cenderung akan melakukan ekspor atas komoditas dengan faktor produksi yang melimpah dan relatif murah pada suatu negara dan akan melakukan impor untuk faktor produksi yang langka atau mahal di negara tersebut. Pendekatan hipotesis Lewis dalam menjelaskan perilaku harga memiliki perbedaan pada komoditas primer dalam jangka panjang, di mana harga komoditas akan cenderung naik (Todaro dan Smith, 2015:612).

Pada akhir tahun 2019 hingga 2020 perekonomian dunia diguncang dengan adanya pandemi Corona Virus Disease 2019 (COVID19) yang dapat mengakibatkan ketidakpastian global (Ben dan Zhang, 2020). Fenomena d COVID-19 ini seperti kondisi Perang dunia II, di mana pada dapat mempengaruhi kegiatan perdagangan internasional. Penerapan kebijakan lockdown atau pembatasan kegiatan masyarakat menyebabkan kegiatan ekonomi menjadi sangat terbatas. Sehingga terjadi penurunan pada tingkat ekspor. Ekspor komoditas primer juga mengalami penurunan karena tertutupnya akses perdagangan untuk masuk ke negara - negara 
tujuan. Dengan adanya wabah COVID-19 Pergerakan nilai ekspor komoditas primer di melemahkan perdagangan internasional yang Negara Indonesia ditunjukkan pada Gambar 1 berdampak pada lemahnya ekonomi dunia. berikut.

\section{Tingkat Ekspor Indonesia}

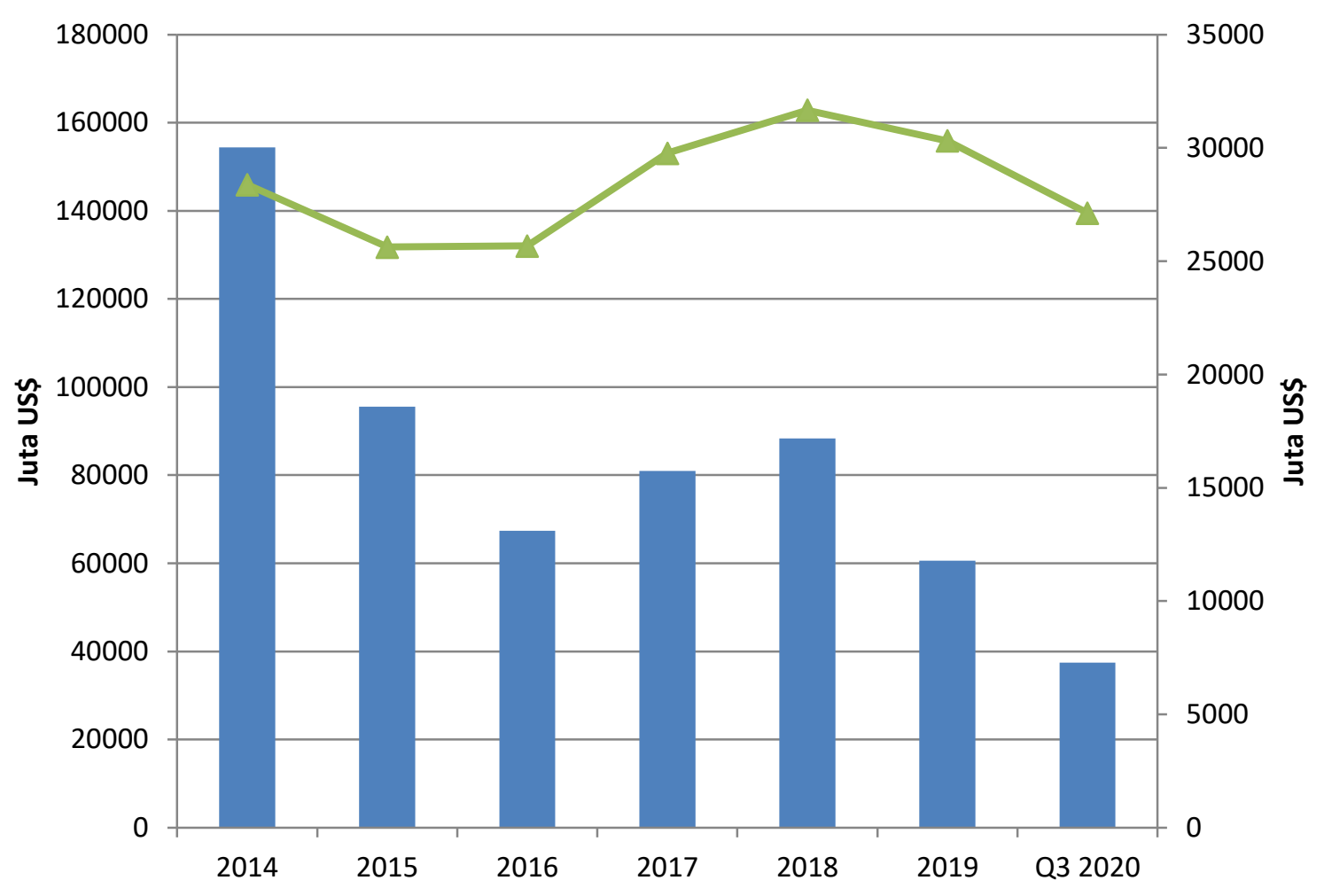

Sumber: BPS Indonesia, 2020

Gambar 1. Pergerakan Nilai Ekspor di Indonesia Tahun 2014 - Q3 2020

Perkembangan nilai ekspor Indonesia selama tahun 2014 - Q3 2020 mengalami fluktuasi. Tahun 2014 dan 2015 berturut - turut mengalami penurunan yang disebabkan karena sektor migas dan non migas. Pada tahun 2019, nilai ekspor di Negara Indonesia mengalami penurunan. Penurunan pada ekspor diakibatkan karena adanya penurunan pada kelompok migas yaitu hasil minyak dan gas (Badan Pusat Statistik, 2019). Penurunan pada akhir tahun 2019 menunjukkan dampak dari adanya Pandemi COVID-19 yang masuk ke Negara Indonesia.
Tepatnya pada Q3 2020 mengalami penurunan sangat tajam dibanding tahun 2019. Pembatasan mobilitas dan kegiatan ekonomi mengakibatkan kinerja perekonomian menurun. Pada kinerja ekspor, mengalami kontraksi karena dampak menurunnya volume perdagangan, maupun rendahnya harga komoditas (BPS, Laporan Perekonomian Indonesia, 2020). Kegiatan ekspor dan impor baik secara langsung maupun tidak langsung dapat berdampak pada depresiasi nilai tukar maupun tingginya tingkat inflasi. 


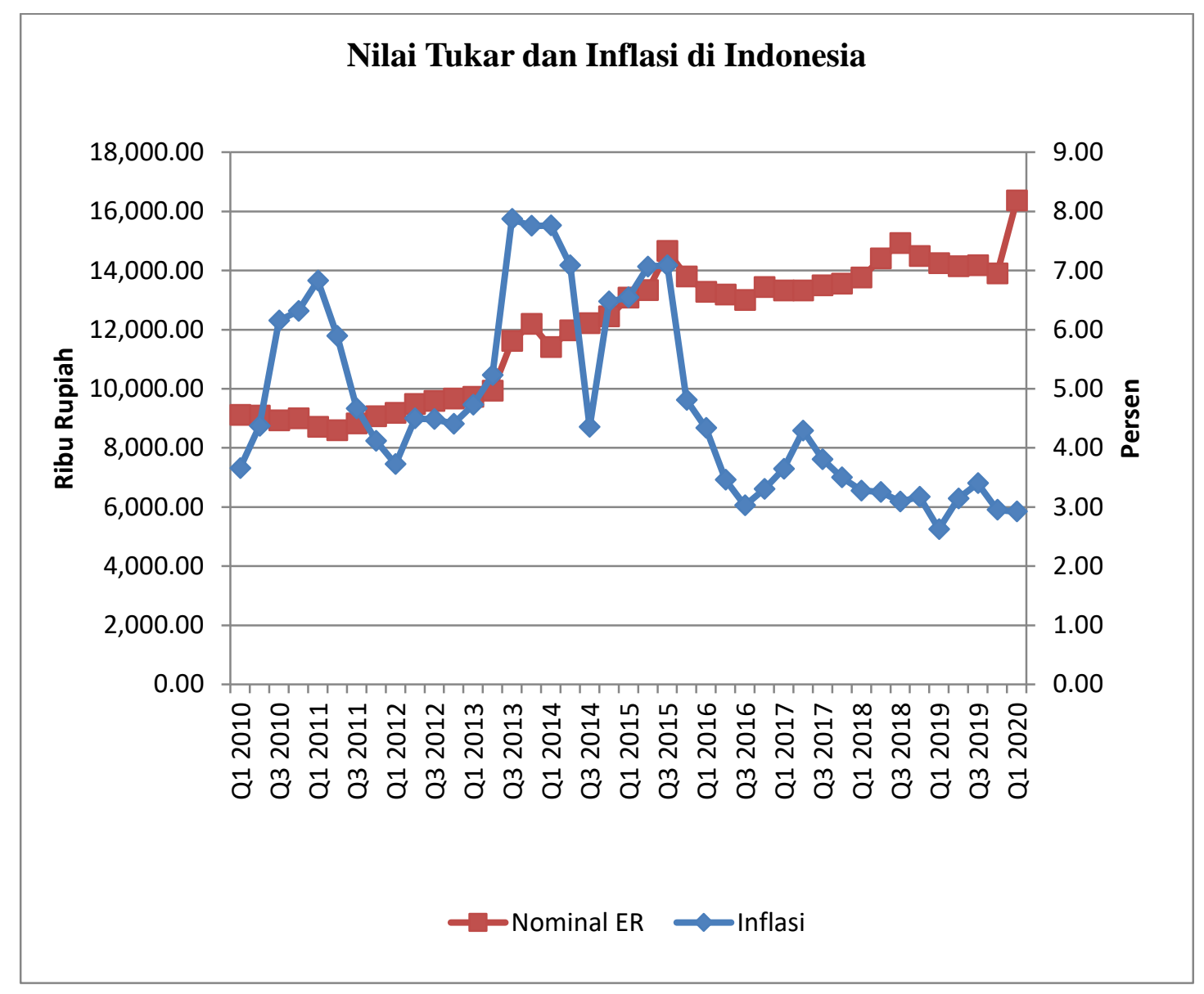

Sumber: IMF, 2020

Gambar 2. Volatilitas Nilai Tukar dan Inflasi Indonesia Tahun 2010Q1- 2020Q1

Tingkat inflasi mengalami penurunan sekitar 2,6 persen pada tahun 2018 dan 2,7 persen pada tahun 2019. Angka inflasi yang cukup rendah ini masih berada di kisaran target pemerintah yaitu antara $2,5 \%-4,5 \%$. Rendahnya tingkat inflasi di Indonesia disebabkan oleh terjaganya permintaan dalam negeri dan juga sebagai keberhasilan kebijakan yang dilakukan oleh pemerintah bersama Bank Indonesia dalam mengendalikan harga komoditas pangan. Terkait dengan harga, perkembangan nilai tukar rupiah terhadap dolar Amerika sepanjang tahun 2019 cenderung melemah yang dipengaruhi oleh dampak ketidakpastian global pada angka Rp. 16.367. Terdepresiasinya nilai tukar sejak kuartal I 2020 terjadi karena meluasnya pandemi COVID-19 (BPS, Laporan Perekonomian Indonesia, 2020). Bank Indonesia juga terus meningkatkan kebijakan stabilisasi dan penyesuaian aliran modal asing di pasar keuangan domestik menekan nilai tukar agar dapat menguat pada kuartal ke dua.
Berkaitan dengan adanya pandemi COVID-19 yang terjadi saat ini, di mana dapat berdampak pada semua sektor ekonomi khususnya perdagangan internasional. Pergerakan pada nilai ekspor secara langsung maupun tidak langsung berdampak pada gejolak harga. Gejolak harga ditunjukkan dengan besarnya tingkat inflasi maupun dari sisi nilai tukar. Besarnya nilai ekspor komoditas primer yang diukur dengan beberapa kategori mengalami penurunan dan kenaikan yang berfluktuatif di saat pandemi COVID-19 melanda dunia. Dengan demikian, pada penelitian ini akan menganalisis hubungan kausalitas dengan granger causality dan keterkaitan dalam jangka panjang dengan analisis cointegration antara ekspor komoditas primer dalam penentuan harga. Selain itu, juga akan memaparkan kondisi pandemi COVID-19 ini yang menunjukkan hasil nilai komoditas primer mengalami penurunan sesuai dengan Prebisch Singer Hypothesis atau tidak. Novelty dalam penelitian ini yaitu adanya 
komparasi antara pendekatan hipotesis yang sejak lama telah ada dengan penyesuaian kondisi saat pandemi COVID-19 pada aspek harga komoditas primer. Penelitian terdahulu hanya membahas tentang trend harga komoditas berdasarkan hipotesis Prebisch Singer belum menggambarkan kondisi atau fenomena pandemi COVID-19. Metode yang digunakan hanya uji unit root, sedangkan dalam penelitian ini telah menggunakan uji kausalitas dan uji kointegrasi yang dapat menggambarkan hubungan dalam jangka panjang.

Rumusan Masalah

Berdasarkan latar belakang yang telah dipaparkan, maka penelitian ini menemukan pertanyaan masalah sebagai berikut:

1. Bagaimana hubungan kausalitas dan keterkaitan dalam jangka panjang antara ekspor komoditas primer terhadap tingkat inflasi dan nilai tukar?

2. Apakah dengan kondisi pandemi COVID-19 ini sesuai dengan Prebisch Singer Hypothesis atau tidak?

Tujuan Penelitian

Dari latar belakang dan rumusan masalah yang diuraikan tersebut, tujuan penelitian ini yaitu:

1. Menganalisis dan mengestimasi hubungan kausalitas dan keterkaitan jangka panjang antara ekspor komoditas primer terhadap tingkat inflasi dan nilai tukar

2. Memaparkan tingkat harga komoditas primer sesuai Prebisch Singer Hypotheis saat kondisi pandemi COVID-19.

\section{LITERATUR REVIEW}

Prebisch dan Singer (1950) menyatakan terdapat penurunan dalam perdagangan untuk negara berkembang yang berkaitan dengan industrialisasi. Analisis pergerakan harga produk primer dan barang jadi didasarkan pada model Raul Prebisch dan Hans Singer. Terjadi efek positif yang timbul antara harga produksi primer dan tren perdagangan. Kontribusi oleh Prebisch dan Singer menekankan persyaratan untuk perdagangan dengan tren menurun (Bloch and Sapsford, 1997). Hipotesis Prebisch-Singer menjelaskan tentang nilai tukar yang berkaitan dengan produk primer yang menunjukkan tren menurun dalam jangka panjang. Penelitian yang dilakukan oleh Sapsford (1985) menunjukkan bahwa masalah ketidakstabilan struktural yang berkontribusi pada tren yang memburuk yang mendukung hipotesis Prebisch Singer.

Kim, et al. (2003) dan Todaro dan Smith (2015) menjelaskan perilaku harga komoditas dalam jangka panjang, sehingga harga komoditas cenderung naik. Tingkat harga akan kembali ke tren nol dan dalam jangka pendek dan dapat kembali menaikkan harga. Harvey, et al. (2010) juga menganalisis tentang hipotesis PrebischSinger di mana harga menunjukkan tren yang menurun disebabkan negara berkembang mengandalkan pendapatan ekspor dari komoditas primer. Spinola (2020) Prebisch Singer Hypothesis tidak valid dalam jangka panjang. Mendapatkan bukti yang bertentangan dengan hipotesis Prebisch Singer yang menyatakan bahwa harga komoditas menunjukkan perilaku unit root, hanya sedikit yang menunjukkan tren negatif yang diprediksi oleh hipotesis Prebisch Singer. Harvey, et al. (2010) menunjukkan adanya tren yang signifikan dan menurun pada harga relatif komoditas primer

\section{METODOLOGI PENELITIAN}

Penelitian ini menggunakan data sekunder berupa data time series dengan rantang waktu bulanan. Periode waktu yang digunakan yaitu bulan Januari tahun 2019 sampai dengan bulan Agustus 2021. Objek penelitian ini yaitu di Negara Indonesia. Variabel yang digunakan dalam penelitian ini antara lain yaitu inflasi, nilai tukar nominal, dan ekspor beberapa kategori komoditas primer. Sumber data yang digunakan dalam penelitian ini berasal dari BPS Indonesia, IMF, dan sumber - sumber lainnya yang kredibel. Operasional variabel yang digunakan antara lain sebagai berikut: 
Tabel 1. Operasional Variabel Penelitian

\begin{tabular}{|c|c|c|c|c|}
\hline No. & Nama Variabel & Variabel Proksi & Keterangan & Sumber Data \\
\hline 1. & $\begin{array}{l}\text { INF (Tingkat } \\
\text { Inflasi) }\end{array}$ & $\begin{array}{l}\text { Consumer Price } \\
\text { Indeks }(\mathrm{CPI})\end{array}$ & Bentuk satuan Indeks & $\begin{array}{l}\text { International Monetary } \\
\text { Fund (IMF) }\end{array}$ \\
\hline 2. & NER (Nilai Tukar) & $\begin{array}{l}\text { Nominal Exchange } \\
\text { Rate }\end{array}$ & per US\$ & $\begin{array}{l}\text { International Monetary } \\
\text { Fund (IMF) }\end{array}$ \\
\hline 3. & EKS_TEMBAKAU & $\begin{array}{l}\text { Tembakau (ada atau } \\
\text { tidak mengandung } \\
\text { pengganti tembakau) }\end{array}$ & $\begin{array}{l}\text { Indeks Unit Value } \\
\text { Ekspor kode SITC }\end{array}$ & $\begin{array}{l}\text { Badan Pusat Statistik } \\
\text { (BPS) Indonesia }\end{array}$ \\
\hline 4. & EKS_KARET & $\begin{array}{l}\text { Karet Alam, getah } \\
\text { alam, dalam bentuk } \\
\text { asal }\end{array}$ & $\begin{array}{l}\text { Indeks Unit Value } \\
\text { Ekspor kode SITC }\end{array}$ & $\begin{array}{l}\text { Badan Pusat Statistik } \\
\text { (BPS) Indonesia }\end{array}$ \\
\hline 5. & EKS_IKAN & $\begin{array}{l}\text { Ikan Segar (hidup atau } \\
\text { mati), dingin atau beku }\end{array}$ & $\begin{array}{l}\text { Indeks Unit Value } \\
\text { Ekspor kode SITC }\end{array}$ & $\begin{array}{l}\text { Badan Pusat Statistik } \\
\text { (BPS) Indonesia }\end{array}$ \\
\hline 6. & EKS_GA & $\begin{array}{l}\text { Gas Alam (Cair atau } \\
\text { tidak) }\end{array}$ & $\begin{array}{l}\text { Indeks Unit Value } \\
\text { Ekspor kode SITC }\end{array}$ & $\begin{array}{l}\text { Badan Pusat Statistik } \\
\text { (BPS) Indonesia }\end{array}$ \\
\hline 7. & EKS_MM & $\begin{array}{l}\text { Minyak mentah } \\
\text { (minyak yang } \\
\text { diperoleh dari mineral) }\end{array}$ & $\begin{array}{l}\text { Indeks Unit Value } \\
\text { Ekspor kode SITC }\end{array}$ & $\begin{array}{l}\text { Badan Pusat Statistik } \\
\text { (BPS) Indonesia }\end{array}$ \\
\hline 8. & EKS_EMAS & $\begin{array}{l}\text { Emas non-moneter } \\
\text { (tidak termasuk bijih } \\
\text { emas) }\end{array}$ & $\begin{array}{l}\text { Indeks Unit Value } \\
\text { Ekspor kode SITC }\end{array}$ & $\begin{array}{l}\text { Badan Pusat Statistik } \\
\text { (BPS) Indonesia }\end{array}$ \\
\hline 9. & EKS_BESI & $\begin{array}{l}\text { Besi dan baja bentuk } \\
\text { batang (termasuk } \\
\text { lapisan tiang pancang) }\end{array}$ & $\begin{array}{l}\text { Indeks Unit Value } \\
\text { Ekspor kode SITC }\end{array}$ & $\begin{array}{l}\text { Badan Pusat Statistik } \\
\text { (BPS) Indonesia }\end{array}$ \\
\hline 10. & EKS_TEMBAGA & Tembaga murni & $\begin{array}{l}\text { Indeks Unit Value } \\
\text { Ekspor kode SITC }\end{array}$ & $\begin{array}{l}\text { Badan Pusat Statistik } \\
\text { (BPS) Indonesia }\end{array}$ \\
\hline
\end{tabular}

\section{Metode Analisis}

Dalam penelitian ini menggunakan dua metode analisis yaitu Granger Causality (Kausalitas Granger) dan Johansen Cointegration Test (Uji Kointegrasi Johansen). Metode Kausalitas Garanger digunakan untuk mengetahui hubungan satu arah atau dua arah antar variabel yang diteliti. Sedangkan uji kointegrasi digunakan untuk menunjukkan hubungan atau keterkaitan dalam jangka panjang antara variabel independen dan variabel dependen. Penelitian ini juga mengadopsi persamaan regresi dari Harvey et al,. (2010). Persamaan regresi yang digunakan dalam penelitian ini antara lain yaitu:

$$
\begin{array}{r}
I N F_{t}=\alpha_{0}+\beta_{1} E K S_{-} T E M B A K A U_{t}+\beta_{2} E K S_{-} K A R E T_{t}+\beta_{3} E K S_{-} I K A N_{t}+\beta_{4} E K S_{-} G A_{t}+ \\
\beta_{5} E K S_{-} M M_{t}+\beta_{6} E K S_{-} E M A S_{t}+\beta_{7} E K S_{-} B E S I_{t}+\beta_{8} E K S_{-} T E M B A G A_{t}+\varepsilon_{t} \ldots \ldots \ldots \ldots . .(1) \\
\text { LogNER }_{t}=\alpha_{0}+\beta_{1} E K S_{-} T E M B A K A U_{t}+\beta_{2} E K S_{-} \text {KARET }_{t}+\beta_{3} E K S_{-} I K A N_{t}+\beta_{4} E K S_{-} G A_{t}+ \\
\beta_{5} E K S_{-} M M_{t}+\beta_{6} E K S_{-} E M A S_{t}+\beta_{7} E K S_{-} B E S I_{t}+\beta_{8} E K S_{-} T E M B A G A_{t}+\varepsilon_{t} \ldots \ldots \ldots \ldots . .(2)
\end{array}
$$

Keterangan :

$\begin{array}{ll}\alpha_{0} & : \text { Intersep/konstanta } \\ \beta_{1}, \beta_{2}, \beta_{3}, \beta_{4} & : \text { Koefisien Variabel } \\ & \text { Independen } \\ \text { INF } & : \text { Tingkat Inflasi (Consumer } \\ & \text { Price Index) }\end{array}$

LogNER : Nilai Tukar Nominal (US\$)
EKS_TEMBAKAU: Indeks Nilai Unit Ekspor

Komoditas Tembakau

EKS_KARET : Indeks Nilai Unit Ekspor Komoditas Karet

EKS_IKAN : Indeks Nilai Unit Ekspor Komoditas Tembakau

EKS_GA : Indeks Nilai Unit Ekspor Komoditas Gas Alam 


\section{EKS_MM \\ EKS_EMAS \\ EKS_BESI
EKS_TEMBAGA : Indeks Nilai Unit Ekspor Komoditas Tembaga \\ $\varepsilon_{t}$ \\ : Error term}

\section{Uji Kausalitas Granger \\ (Granger Causality Test)}

Pengujian kausalitas digunakan untuk mengetahui hubungan antar variabel yaitu merupakan hubungan satu arah atau dua arah. Kausalitas merupakan hubungan dua arah atau dapat disebut dengan hubungan timbal balik, jadi jika dalam hasil pengujian dihasilkan adanya

$Y_{i}=\gamma_{0}+\sum_{z=1}^{p} \gamma_{z} \gamma_{t-z}+\sum_{i=1}^{p} \lambda_{i} X_{t-1}+\mu_{t}$

$X_{i}=\varphi_{0}+\sum_{z=1}^{p} \delta_{z} X_{t-z}+\sum_{i=1}^{p} \psi_{i} Y_{t-1}+\varepsilon_{t}$

Di mana: $Y_{1}$ dan $X_{1}$ yaitu variabel yang diuji, $\mu_{t}$ dan $\varepsilon_{t}$ adalah error term (istilah kesalahan), notasi $\mathrm{t}$ menunjukkan tentang periode waktu, sedangkan $\mathrm{z}$ dan i menunjukkan angka dari lag. Hipotesis nol adalah $\lambda_{i}=\psi_{i}=0$ untuk semua i. Sedangkan hipotesis alternatif di mana $\lambda_{i} \neq 0$ dan $\psi_{i} \neq 0$ untuk beberapa i, jika koefisien $\lambda_{i}$ signifikan tetapi $\psi_{i}$ tidak signifikan, maka $\mathrm{X}$ kausalitas maka dalam model ekonometrika tidak terdapat variabel dependen melainkan semua merupakan variabel independen. Dalam penelitian ini menggunakan model kausalitas yang dikemukakan oleh Granger. Uji kausalitas Granger menggambarkan hubungan yang ada di semua variabel. Uji kausalitas Granger juga dapat digunakan untuk menguji hubungan sebab akibat antara dua variabel. Jika nilai $\mathrm{P}$ dari variabel $\mathrm{Y}$ secara signifikan berkontribusi untuk meramalkan nilai variabel $X$ lainnya, sehingga $Y$ memiliki hubungan sebab akibat dengan $\mathrm{X}$ dan sebaliknya. Uji kausalitas ini didasarkan pada Uji Standar Granger Tahun 1969 bahwa nilai masa lalu dari variabel $\mathrm{Y}$ berkontribusi secara signifikan untuk meramalkan nilai dari variabel lain yaitu $X_{t-1}$ ketika Y dikatakan ada kausalitas granger terhadap $X$ dan begitu juga sebaliknya. Persamaan regresi yang diadopsi dari Harvey,et al. (2010) seperti di bawah: kausalitas granger terhadap Y, namun jika kedua koefisiennya signifikan maka kausalitas berjalan dua arah.

Didasarkan pada persamaan 1 tentang model penelitian dan variabel yang digunakan akan disubstitusikan pada model uji kausalitas granger persamaan (3) dan (4). Sehingga spesifikasi model metode Granger Causality yang digunakan dalam penelitian ini yaitu:

$$
\begin{aligned}
I N F_{t}=\gamma_{0} & +\sum_{z=1}^{p} \gamma_{z} E K S_{-} T E M B A K A U_{t}+\sum_{i=1}^{p} \lambda_{i} E K S_{-} K A R E T_{t}+\sum_{i=1}^{p} \delta_{i} E K S_{-} I K A N_{t} \\
& +\sum_{i=1}^{p} \varphi_{i} E K S_{-} G A_{t}++\sum_{i=1}^{p} \delta_{i} E K S_{-} M M_{t}+\sum_{i=1}^{p} \theta_{i} E K S_{-} E M A S_{t} \\
+ & +\sum_{i=1}^{p} \rho_{i} E K S_{-} B E S I_{t}+\sum_{i=1}^{p} \omega_{i} E K S_{-} T E M B A G A_{t}+\mu_{t} \\
\operatorname{LogNER}_{t}=\gamma_{0} & +\sum_{z=1}^{p} \gamma_{z} E K S_{-} T E M B A K A U_{t}+\sum_{i=1}^{p} \lambda_{i} E K S_{-} K A R E T_{t}+\sum_{i=1}^{p} \delta_{i} E K S_{-} I K A N_{t} \\
& +\sum_{i=1}^{p} \varphi_{i} E K S_{-} G A_{t}++\sum_{i=1}^{p} \delta_{i} E K S_{-} M M_{t}+\sum_{i=1}^{p} \theta_{i} E K S_{-} E M A S_{t} \\
& ++\sum_{i=1}^{p} \rho_{i} E K S_{-} B E S I_{t}+\sum_{i=1}^{p} \omega_{i} E K S_{-} T E M B A G A_{t}+\mu_{t}
\end{aligned}
$$




\section{Uji Kointegrasi Johansen (Johansen-Cointegration Test)}

Pengujian ini dilakukan untuk mengetahui adanya keterkaitan dan keseimbangan dalam jangka panjang atau tidak. Dalam hal ini uji kointegrasi menggunakan pendekatan kointegrasi Johanson. Uji kointegrasi pada model dapat dilihat dari nilai trace statistic dan maximum eigenvalue statistici (Gujarati dan Porter, 2009). Apabila nilai trace statistic dan maximum eigenvalue statistic lebih besar dari nilai kritis maka terkointegrasi, begitu juga dengan sebaliknya.

\section{HASIL ESTIMASI DAN PEMBAHASAN}

\section{Hasil Estimasi Uji Kausalitas Granger (Granger Causaity Test)}

Uji kausalitas digunakan untuk mengetahui hubungan antar variabel yang ditunjukkan dengan hubungan satu arah atau dua arah. Kausalitas merupakan hubungan dua arah, jadi jika dalam hasil pengujian dihasilkan adanya kausalitas maka dalam model ekonometrika tidak terdapat variabel dependen melainkan semua merupakan variabel independen. Hubungan kausalitas pada Tabel 2.

Tabel 2. Hasil Uji Kausalitas Granger

\begin{tabular}{lc}
\hline \multicolumn{1}{c}{ Hubungan Kausal } & Model Keseluruhan \\
\hline EKS_TEMBAKAU does not Granger Cause INF & - \\
\hline EKS_KARET does not Granger Cause INF & $\sqrt{ }$ \\
\hline EKS_IKAN does not Granger Cause INF & - \\
\hline EKS_GA does not Granger Cause INF & $\sqrt{ }$ \\
\hline EKS_MM does not Granger Cause INF & - \\
\hline EKS_EMAS does not Granger Cause INF & - \\
\hline EKS_BESI does not Granger Cause INF & - \\
\hline EKS_TEMBAGA does not Granger Cause INF & $\sqrt{ }$ \\
\hline EKS_TEMBAKAU does not Granger Cause NER & - \\
\hline EKS_KARET does not Granger Cause NER & $\sqrt{ }$ \\
\hline EKS_IKAN does not Granger Cause NER & $\sqrt{ }$ \\
\hline EKS_GA does not Granger Cause NER & $\sqrt{ }$ \\
\hline EKS_MM does not Granger Cause NER & - \\
\hline EKS_EMAS does not Granger Cause NER & - \\
\hline EKS_BESI does not Granger Cause NER & - \\
\hline EKS_TEMBAGA does not Granger Cause NER & \\
\hline $\begin{array}{l}\sqrt{ }) \text { = memiliki hubungan satu arah } \\
(\sqrt{ })=\text { memiliki hubungan dua arah } \\
(-)\end{array}$ & tidak memiliki hubungan \\
\hline
\end{tabular}

Hubungan kausalitas pada Tabel 2 balik. Hanya terdapat hubungan satu arah memaparkan hasil untuk variabel INF, NER, (searah). Hal tersebut menunjukkan bahwa EKS_TEMBAKAU, EKS_KARET, EKS_IKAN, komoditas primer besar kecilnya nilai unit yang EKS_GA, EKS_MM, EKS_EMAS, EKS_BESI, dihasilkan tidak hanya dapat dipengaruhi oleh dan EKS_TEMBAGA. Penjelasan mengenai uji kausalitas pada model secara keseluruhan menunjukkan bahwa nilai dari komoditas primer di Indonesia tidak terdapat dua hubungan timbal variabel inflasi dan nilai tukar, tetapi terdapat dipengaruhi oleh aspek lainnya. Hasil uji kausalitas hubungan satu arah antara variabel EKS_KARET dengan INF; EKS_IKAN dengan 
INF dan EKS_MM dengan INF pada Prob. $\alpha<$ $5 \%$. Selain itu tidak ada hubungan satu arah maupun dua arah antar variabel. Dengan demikian, komoditas karet, ikan dan minyak mentah (MM) dapat dipengaruhi oleh tingkat inflasi, dikarenakan hasil hanya searah maka berarti tingkat inflasi tidak hanya dipengaruhi oleh komoditas tersebut tetapi terdapat pengaruh dari faktor komoditas primer lain.

Sedangkan pada variabel EKS_TEMBAKAU dengan NER, EKS_IKAN dengan NER, EKS_GA dengan NER, dan EKS_MM dengan NER hanya memiliki hubungan searah pada Prob. $\alpha<5 \%$. Selain itu tidak ada hubungan satu arah maupun dua arah antar variabel. Artinya, komoditas Tembakau, Ikan, Gas Alam dan minyak mentah (MM) dapat dipengaruhi oleh nilai tukar, dikarenakan hasil hanya searah maka berarti nilai tukar tidak hanya dipengaruhi oleh komoditas tersebut saja tetapi terdapat pengaruh dari faktor komoditas primer lain.

Hasil penelitian Geronimi dan Taranco (2018) menjelaskan bahwa penurunan harga komoditas pada tahun 2014 tidak mengubah syarat atau ketentuan perdagangan, tetapi setelah masuk rezim baru tingkat harga lebih tinggi dan dinamis sejak tahun 2006. Eksportir komoditas primer sebagian besar didorong untuk mengadopsi kebijakan pro ekspor, sehingga akan mengarah pada tingginya pasokan komoditas primer di pasar global sehingga harga komoditas menjadi rendah pada tahun 2005. Hal tersebut sebagai akibat dari perubahan kebijakan ekonomi secara global.

\section{Hasil Estimasi Uji Kointegrasi (Johanson Cointegration Test)}

Hasil uji kointegrasi variabel penelitian seperti pada Tabel 2, uji kointegrasi antara INF, EKS_TEMBAKAU, EKS_KARET, EKS_IKAN, EKS_GA, EKS_MM, EKS_EMAS, EKS_BESI, dan EKS_TEMBAGA memperhitungkan nilai dari trace statistic dan max eigen value dengan nilai critical value. Perbandingan trace statistic dan max eigen value memiliki nilai lebih besar dari critical value pada tingkat $1 \%$ dan $5 \%$. Jadi, berdasarkan hasil pengujian menunjukkan bahwa antar variabel terkointegrasi. Sehingga jika antar variabel terkointegrasi mengindikasikan terdapat hubungan jangka panjang antar variabel yang diteliti. Hal tersebut juga ditunjukkan dengan nilai Prob. trace statistic dan critical value kurang dari $5 \%$ atau 0.05 .

Tabel 3. Hasil Uji Johanson-Cointegration pada INF

\begin{tabular}{|c|c|c|c|c|}
\hline Kategori & Tingkatan & Nilai & Prob. & Ket. Kointegrasi \\
\hline \multirow{3}{*}{ Trace-Statistic } & $1 \%$ & 374.7095 & \multirow{3}{*}{0.0000} & \multirow{6}{*}{ Ya } \\
\hline & $5 \%$ & 260.4897 & & \\
\hline & $10 \%$ & 187.7290 & & \\
\hline \multirow{3}{*}{ Citical Value } & $1 \%$ & 197.3709 & \multirow{3}{*}{0.0000} & \\
\hline & $5 \%$ & 159.5297 & & \\
\hline & $10 \%$ & 125.6154 & & \\
\hline \multirow{3}{*}{ Max Eigen Value } & $1 \%$ & 114.2198 & \multirow{3}{*}{0.0001} & \multirow{6}{*}{ Ya } \\
\hline & $5 \%$ & 72.76072 & & \\
\hline & $10 \%$ & 62.81061 & & \\
\hline \multirow{3}{*}{ Critical Value } & $1 \%$ & 58.43354 & \multirow{3}{*}{0.0004} & \\
\hline & $5 \%$ & 52.36261 & & \\
\hline & $10 \%$ & 46.23142 & & \\
\hline
\end{tabular}

Sumber: Data dari E-Views, diolah 
Tabel 3 menunjukkan hasil uji kointegrasi dengan variabel dependen inflasi (INF) dengan variabel independen komoditas primer. Hasil menunjukkan bahwa komoditas primer EKS_TEMBAKAU, EKS_KARET, EKS_IKAN, EKS_GA, EKS_MM, EKS_EMAS, EKS_BESI, dan EKS_TEMBAGA memiliki hubungan jangka panjang (terkointegrasi) dengan tingkat inflasi. Hal tersebut berarti terdapat hubungan saling mempengaruhi antara tingkat inflasi dan nilai unit komoditas primer dalam jangka panjang baik itu hubungan searah maupun timbal balik.

Tabel 4. Hasil Uji Johanson-Cointegration pada NER

\begin{tabular}{|c|c|c|c|c|}
\hline Kategori & Tingkatan & Nilai & Prob. & Ket. Kointegrasi \\
\hline \multirow{3}{*}{ Trace-Statistic } & $1 \%$ & 371.3489 & \multirow{3}{*}{0.0000} & \multirow{6}{*}{$\mathrm{Ya}$} \\
\hline & $5 \%$ & 261.2849 & & \\
\hline & $10 \%$ & 186.5321 & & \\
\hline \multirow{3}{*}{ Citical Value } & $1 \%$ & 197.3709 & \multirow{3}{*}{0.0000} & \\
\hline & $5 \%$ & 159.5297 & & \\
\hline & $10 \%$ & 125.6154 & & \\
\hline \multirow{3}{*}{ Max Eigen Value } & $1 \%$ & 110.0640 & \multirow{3}{*}{0.0000} & \multirow{6}{*}{$\mathrm{Ya}$} \\
\hline & $5 \%$ & 74.75280 & & \\
\hline & $10 \%$ & 60.62287 & & \\
\hline \multirow{3}{*}{ Critical Value } & $1 \%$ & 58.43354 & \multirow{3}{*}{0.0008} & \\
\hline & $5 \%$ & 52.36261 & & \\
\hline & $10 \%$ & 46.23142 & & \\
\hline
\end{tabular}

Sumber: Data dari E-Views, diolah

Pada Tabel 4 menunjukkan hasil estimasi uji kointegrasi dengan variabel dependen nilai tukar (NER). Hasil uji kointegrasi antara NER dengan EKS_TEMBAKAU, EKS_KARET, EKS_IKAN, EKS_GA, EKS_MM, EKS_EMAS, EKS_BESI, dan EKS_TEMBAGA memperhitungkan nilai dari trace statistic dan max eigen value dengan nilai critical value pada tingkat $1 \%$ dan 5\% sama seperti model sebelumnya. Hasil pengujian menunjukkan bahwa antar variabel terjadi kointegrasi. Berarti mengindikasikan terdapat hubungan dalam jangka panjang antar variabel independen dan dependen. Variabel NER memiliki hubungan jangka panjang dengan variabel EKS_TEMBAKAU, EKS_KARET, EKS_IKAN, EKS_GA, EKS_MM, EKS_EMAS, EKS_BESI, dan EKS_TEMBAGA.

Dalam jangka panjang dinamika harga komoditas disesuaikan dengan faktor permintaan, penawaran dan pasar (Geronimi dan Taranco, 2018). Faktor permintaan dalam komoditas perdagangan internasional pada negara berkembang diorganisir oleh adanya transisi ekologi dan perubahan iklim.

\section{PEMBAHASAN}

Dalam Prebisch Singer Hypothesis yang mana negara menunjukkan tren menurun dalam jangka panjang pada perdagangan komoditas untuk negara berkembang (Salvatore, 2013). Tren tersebut disebabkan karena ada spesialisasi pada struktur produk yang lebih produktif dengan elastisitas pendapatan yang kecil pada permintaan komoditas primer. Kenaikan pada pendapatan akan meningkatkan harga relatif dari komoditas primer yang disebabkan karena penurunan tingkat perdagangan dalam jangka panjang (Harvey et al., 2010 dan Spinola, 2020). Menurut Winkelried (2018) bahwa dukungan pendekatan Hipotesis Prebisch Singer sangat terbatas dan Spinola (2020) menyatakan bahwa Prebisch Singer Hypothesis tidak valid dalam jangka panjang. Hasil penelitian sebelumnya berbeda 
dengan hasil yang didapatkan dalam penelitian ini. Dalam penelitian ini di Negara Indonesia yang termasuk negara berkembang nilai unit dari komoditas primer mengalami trend kenaikan, hanya pada kondisi tertentu yang mengalami penurunan dikarenakan dampak dari suatu kejadian yang terjadi secara tidak terprediksi atau terencana, misalnya terjadi krisis akibat covid-19. Trend komoditas primer setelah kondisi pandemi mulai mereda akan mengalami trend kenaikan dan menjadi lebih baik. Begitu pula apabila dilihat dari keterkaitan dan keterpengaruhan dalam jangka panjang dinyatakan valid dan signifikan. Sehingga dalam hal ini menolak Prebisch Singer Hypothesis. Winkelried (2018) juga beranggapan bahwa pengujian harga komoditas pada hipotesis sering ditolak karena model alternatif menunjukkan trend cukup fleksible untuk karakterisasi perilaku harga. Fleksibilitas dalam memperhitungkan adanya efek struktural atau fenomena terkait sehingga menunjukkan trend atau siklus tertentu. Siklus atau trend akan selalu berkembang seiring waktu.

Hasil sejalan dengan penelitian dari Kim et al (2003) dan Spinola (2020) menemukan bukti yang bertentangan dengan hipotesis Prebisch Singer yang menyatakan bahwa harga komoditas menunjukkan perilaku unit root, hanya sedikit yang menunjukkan tren negatif yang diprediksi oleh hipotesis Prebisch Singer. Harvey, et al. (2010) menunjukkan adanya tren yang signifikan dan menurun pada harga relatif komoditas primer. Dalam jangka panjang tren yang menurun menjadi relevan Prebisch Singer Hypothesis untuk fenomena pada sebagian besar komoditas primer. Sedangkan untuk hipotesis Lewis juga dapat berperan dalam menjelaskan perilaku harga tertentu tetapi dalam jangka panjang tidak ada bukti bahwa harga relatif akan cenderung ke atas. Hipotesis Prebisch Singer dalam mengimplikasikan harga komoditas sulit untuk disesuaikan dengan fenomena secara global. Penurunan berkelanjutan pada harga akan lebih baik apabila diartikan sebagai penurunan jangka panjang daripada trend sekuler. Penekanan pada pendekatan trend lokal bukan global pada harga komoditas Winkelried (2018).

Dalam meningkatkan produktivitas tercermin dalam harga dan nilai unit komoditas yang lebih rendah, sehingga di negara berkembang syarat perdagangan harus diperbaiki seiring dengan waktu. Syarat perdagangan akan mambaik berkaitan dengan tingkat kinerja ekspor pasca pandemi mereda. Di negara berkembang tidak memiliki hubungan timbal balik pada kegiatan ekspor komoditas primer sehingga menjadi memburuk dibandingkan dengan negara maju (Salvatore, 2013). Hal tersebut diakibatkan karena peningkatan produktivitas komoditas primer umumnya cenderung lebih kecil daripada manufaktur. Tingkat harga dan biaya pada barang manufaktur harus disesuaikan dengan harga dan nilai unit dari barang komoditas. Selain itu, penurunan pada kondisi perdagangan di negara berkembang diakibatkan oleh peningkatan permintaan barang manufaktur yang cenderung lebih cepat daripada ekspor komoditas primer. Ditunjukkan juga pada tingkat elastisitas pendapatan permintaan barang manufaktur yang jauh lebih tinggi daripada barang komoditas primer. Berdasarkan hasil estimasi data menggunakan uji kausalitas granger bahwa hanya terjadi hubungan searah antara ekspor komoditas primer dengan tingkat inflasi dan nilai tukar. Hasil estimasi dengan uji kointegrasi yang menunjukkan keterkaitan jangka panjang bahwa variabel ekspor komoditas primer memiliki hubungan dalam jangka panjang terhadap inflasi dan nilai tukar. Berkaitan dengan penelitian Geronimi dan Taranco (2018) menunjukkan pergeseran harga komoditas primer belum pernah terjadi pada abad ke-20, sehingga dapat menjadi peluang untuk negara berkembang yang akan berspesialisasi dalam ekspor komoditas primer.

Dengan demikian penelitian ini menolak hipotesis Prebisch Singer dan sesuai atau sepakat dengan hipotesis Lewis. Hasil penelitian ini juga sejalan dengan penelitian yang dilakukan oleh Kim et al (2003), Harvey (2010), Winkelried (2018) dan Spinola (2020). Dengan adanya pandemi ini juga memungkinkan kegiatan ekspor dan kinerja ekspor menjadi yang terganggu yang berkaitan erat dengan tingkat inflasi dan nilai tukar pada masa mendatang. Apabila dilihat dari Hipotesis Lewis terdapat hal menarik yang dapat diadopsi yaitu di mana terdapat perilaku harga komoditas primer yang berperan dalam jangka panjang, sehingga harga komoditas primer akan 
cenderung naik. Hal tersebut dapat diartikan bahwa harga komoditas primer akan dapat bersaing di perdagangan internasional.

\section{SIMPULAN DAN SARAN}

\section{Simpulan}

1. Hasil estimasi data dengan uji kausalitas menunjukkan hubungan satu arah antara variabel EKS_KARET, EKS_IKAN, EKS_MM dengan variabel dependen INF. Begitu juga dengan variabel dependen nilai tukar hanya terdapat hubungan searah yaitu antara EKS_TEMBAKAU, EKS_IKAN, EKS_GA, dan EKS_MM. Selain itu tidak ada hubungan dua arah maupun satu arah.

2. Hasil uji kointegrasi menunjukkan bahwa terdapat hubungan keterkaitan dalam jangka panjang antara variabel inflasi dengan semua variabel independen yaitu EKS_TEMBAKAU, EKS_KARET, EKS_IKAN, EKS_GA, EKS_MM, EKS_EMAS, EKS_BESI, dan EKS_TEMBAGA sebagai komoditas primer. Sehingga hasil ini tidak sesuai dengan Prebisch Singer Hypothesis, tetapi hasil penelitian ini sesuai dan mendukung dengan Lewis Hypothesis.

3. Pada saat kondisi pandemi COVID-19 yang terjadi saat ini juga menggambarkan tingkat kinerja ekspor yang terganggu. Hal tersebut disebabkan karena pembatasan kegiatan sosial dan ekonomi (lockdown) yang berakibat pada penurunan ekspor komoditas primer. Tingkat permintaan yang menurun berdampak pada tingkat inflasi maupun nilai tukar dalam jangka panjang.

\section{Saran}

Upaya yang dapat dilakukan yaitu meningkatkan output komoditas primer yang ada di dalam negeri dan optimalisasi penggunaan produk dalam negeri. Bertepatan dengan fenomena pandemi COVID-19 yang menerapkan pembatasan kegiatan ekonomi luar negeri, maka dapat menerapkan strategi mengutamakan kegiatan ekonomi dalam negeri. Sehingga aktifitas ekonomi dalam negeri dapat terkendali. Harapannya dalam jangka panjang dapat ekspansi kinerja ekspor komoditas primer. Upaya pemerintah dalam program pemulihan ekonomi nasional harus dilakukan percepatan.

\section{DAFTAR PUSTAKA}

Al-Yousif, K. Y. 2006. On the Role Export in the Economic Growth of Malaysia: A Multivariate Analysis. International Economic Journal. Vol. 13 No. 13

Badan Pusat Statistik. 2019. Laporan Keuangan Perekonomian Indonesia 2019. BPS Statistik Indonesia.

Badan Pusat Statistik. 2020. Laporan Keuangan Perekonomian Indonesia 2020. BPS Statistik Indonesia.

Ben Xi, Lin dan Zhang, Y. 2020. Impact of the COVID-19 pandemic on agricultural exports. Journal of Integrative Agriculture 2020, 19(12): 2937-2945

Bloch, H. dan Sapsford, D. 1997. Some Estimates of Prebisch and Singer Effect on the Terms of Trade between Primary Producers and Manufacturers.World Development. Vol. 25, No. 11, pp. 1873-1 884,1997

Deliarnov. 2012. Perkembangan Pemikiran Ekonomi edisi Ketiga. Jakarta: Rajawali Press.

Geronimi, Vincent dan Taranco, Armand. 2018. Revisiting the Prebisch-Singer hypothesis of a secular decline in the terms of trade of primary commodities (1900-2016). A dynamic regime approach. Resources Policy

Gujarati, D.N. dan Porter, D.C. 2009. Basic Econometric. Fifth Edition. New York: The McGraw-Hill

Harvey, D.I., Kellard, N.M., Madsen, J.B., Wohar, M.E. 2010. The PrebischSinger Hypothesis: Four Centuries of Evidence. The Review of Economics and Statistics 92, 367-377.

Kim, T., S. Pfaffenzeller, A. Rayner, and P. Newbold. 2003. Testing for Linear Trend, with Application to Relative Primary Commodity Prices. Journal of Time Series Analysis 24 (2003), 539551. 
Nurjaka dan Oman, Asep. 2003. Intisari Ekonomi. Bandung: Pustaka Setia.

Salvatore, Dominick. 2013. International Economics 11th Edition. United States of America: Fordham University

Sapsford, D. 1985. The Prebisch-Singer Terms of Trade Hypotesis Some New Evidence. USA: International Monetary Ftind Washington, DC 20431

Singer, H., 1950, The distribution of gains between investing and borrowing countries, American Economic Review 40, Pand Proceedings, May, 473-485.

Spinola, Danilo. 2020. Uneven development and the balance of payment constrained model: Term of Trade, Economic
Cycle, and Productivity Catching-Up. Structural Change and Economic Dynamics 54. 220-232.

Svedberg, Peter dan Tilton, John E. 2011. Longterm trends in the Real real prices of primary commodities: Inflation bias and the Prebisch-Singer hypothesis. Resources Policy 36 (2011) 91-93

Todaro, M.P. dan Smith, S.C. 2015. Economic Development $12^{\text {th }}$ Edition. The George Washington University.

Winkelried, Diego. 2018. Unit roots, flexible trends, and the Prebisch-Singer hypothesis. Journal of Development Economics $132 \quad$ (2018) 1-17 